\title{
B-Cell Receptor Binding
}

National Cancer Institute

\section{Source}

National Cancer Institute. B-Cell Receptor Binding. NCI Thesaurus. Code C40476.

A process that involves the binding of an antigen to the transmembrane B cell receptor, an IgD molecule. These interactions are involved in signaling the $B$ cell to be activated and to participate in immune function. 